\title{
Supplier Selection Of Upper Arm and Lower Arm Pantograph Jack Using AHP and TOPSIS Methods
}

\author{
Hery Hamdi Azwir ${ }^{1}$, Fuad Hasan ${ }^{2}$, Hirawati Oemar ${ }^{3}$ \\ ${ }^{1,2)}$ Faculty of Technology, Industrial Engineering Department, President University \\ JI. Ki Hajar Dewantara, Kota Jababeka, Cikarang, Bekasi - Indonesia 17530 \\ Email: ${ }^{1}$ hery.azwir@president.ac.id, ${ }^{2}$ apip.hasan@gmail.com \\ ${ }^{3)}$ Faculty of Technology, Industrial Engineering Department, Bandung Islamic University \\ Jl. Taman Sari, Bandung - Indonesia 40132 \\ Email: hirawatio@yahoo.co.id
}

\begin{abstract}
Cost reduction and multi sourcing program is one of the ways used by companies to survive in business competition. Supplier selection process conducted by PT. MTM aims to get suppliers capable of supplying the needs in a sustainable manner with quality products and competitive prices. The company needs a method to select suppliers that can supply upper arm and lower arm components for pantograph jack products. The research is done through analyzing supplier selection process by PT. MTM, examines the criteria used, and then implements the AHP and TOPSIS methods in the process to gain alternative supplier priorities and reduced purchase costs. To speed up data processing, this study utilizes Expert Choice 11 software. The result of analysis using AHP and TOPSIS is two suppliers will supply the components in PT. MTM.
\end{abstract}

Keywords: AHP; multi sourcing; cost reduction; panthograph jack; supplier; TOPSIS

\begin{abstract}
Abstrak
Pengurangan biaya dan program multi-sumber adalah salah satu cara yang digunakan oleh perusahaan untuk tetap bertahan dalam persaingan bisnis. Proses pemilihan pemasok dilakukan oleh PT. MTM bertujuan untuk membuat pemasok mampu memasok kebutuhan secara berkelanjutan dengan produk-produk berkualitas dan harga bersaing. Perusahaan memerlukan metode untuk memilih pemasok yang dapat memasok komponen lengan atas dan bawah untuk produk-produk jack pantograph. Penelitian ini dilakukan dengan menganalisis proses pemilihan pemasok yang dilakukan oleh PT. MTM, memeriksa kriteria yang digunakan, dan kemudian menerapkan metode AHP dan TOPSIS dalam proses untuk mendapatkan prioritas pemasok alternatif dan mengurangi biaya pembelian. Untuk mempercepat pengolahan data, penelitian ini memanfaatkan software Expert Choice 11. Dari hasil analisis dengan metode AHP dan TOPSIS, didapatkan dua pemasok yang akan memasok komponen di PT. MTM.
\end{abstract}

Kata kunci: AHP; multi sourcing; penurunan biaya; panthograph jack; supplier; TOPSIS

\section{Introduction}

The selection of suppliers in the era of globalization is no longer just a matter of comparing the price of the acquisition of goods, but has been far more complex. Along with the development of technology and information, consumers have considered various other factors such as delivery, quality of goods and services, production capacity, even safety. Weber (Weber, 1991) revealed that there were 23 criteria that could be used in the supplier selection process.

PT. Menara Terus Makmur (MTM) is a manufacturing company in which one of the products produced is the pantograph jack. When this research was conducted, customers of the pantograph jack product asked MTM to reduce the selling price of the product by $30 \%$ from the previous year's selling price. This makes MTM must evaluate the cost structure of making the pantograph jack product and reduce the cost of the manufacturing process and the purchase of its components.

Pantograph jack is a type of motor vehicle jack that has a shape like a pantograph. This jack is used by several motor vehicle manufacturers as OEM (Original Equipment Manufacturing) goods in new vehicles they 
produce. The material of this product is made from steel plates which are processed using a press method by a press stamping machine with a certain capacity, according to the shape and characteristics of each part.

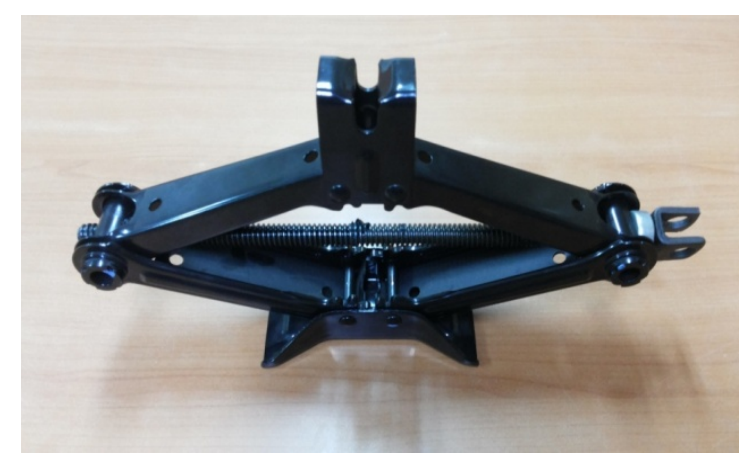

Figure 1. Pantograph jack

From the pantograph jack product cost structure, it is known that $85 \%$ of the total cost of the product is components purchased from suppliers, and of the total cost of these components, $55 \%$ are the upper arm and lower arm components. At present, the upper arm and lower arm components are supplied by one supplier, namely PT. Indotech Metal Nusantara. By only relying on one supplier, the risk of supply delays will be greater, if at any time there is a problem with the supplier. Therefore, multi-sourcing becomes mandatory for important components purchased from suppliers.

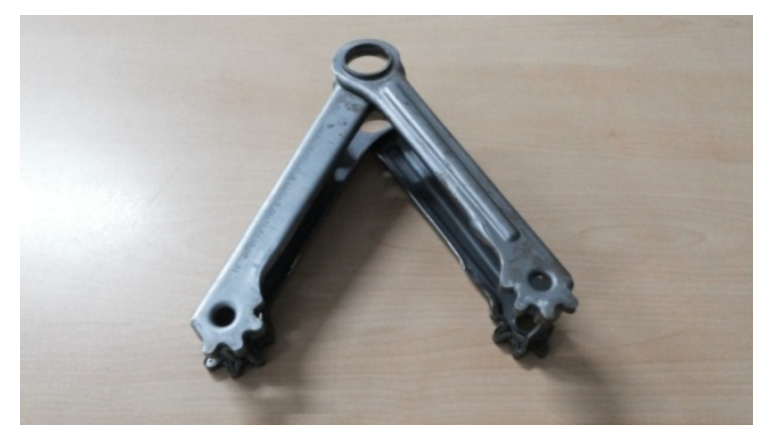

Figure 2. Upper arm dan lower arm

To get the expected cost reduction, the purchasing department must find a new supplier as another sourcing of the upper arm and lower arm components. In finding and deciding on new suppliers, it is necessary to develop a methodology for supplier selection process to decide suppliers who can supply these products at competitive prices, good quality, on-time delivery, and good technical support.

Decision making is the study of identifying and selecting alternatives based on the values and desires of the decision maker. Making a decision implies that there are several alternative choices that must be considered, and in certain cases, not only identifying as many alternatives as possible, but choosing one that is suitable and meets the objectives, values, wishes, and so on.

According to Baker et al (Baker, 2001), decision making must begin with the identification of decision makers and stakeholders in the decision, reducing the possibility of disagreement in identifying problems, goals, needs, and criteria. In decision making with criteria that are more than one (multi-criteria), there are several methods incorporated in MCDM (Multi Criteria Decison Making). A number of MCDM methods are described in (Greco, Ehrgott, \& Figueira, 2016) also described in (Zopounidis \& Doumpos, 2016).

Criteria and sub-criteria data in selecting suppliers in MTM is data that has the following characteristics: (1) Has a clear hierarchical structure, (2) There is no dependency between one criterion with other criteria, (3) Criteria and sub-criteria have input data that are clear, (4) Using quantitative and qualitative data. With the characteristics of the available data, the method that is quite suitable for conducting the supplier selection process is the AHP (Analytical Hierarchy Process) method and TOPSIS (Technique for Order by Similarity to Ideal Solution).

The combination of AHP and TOPSIS is quite widely used in solving cases of decision making. Some published studies has shown the effectiveness of the integration of AHP and TOPSIS and among them decision making for undergraduate defense (Sari, Windarto, Hartama, \& Solikhun, 2018), project management (Jabbarzadeh, 2018), selection of chemical suppliers (Munir, 2017 ), forestry management (Nilsson, Nordström, \& Öhman, 2016), machine selection (Karim \& Karmaker, 2016), software selection (Hanine, Boutkhoum, Tikniouine, \& Agouti, 2016), and evaluation of restaurant service quality (Yildiz \& Karmaker Yildiz, 2015).

AHP method has advantages that can cover the shortcomings of other methods, (Saaty, 1993), namely: (1) Providing methods for weighting between criteria by pairwise comparison assessments. This method covers the shortcomings of the TOPSIS method which does not have a method for weighting 
qualitative data. (2) Having a consistency checking method in assessing criteria or alternatives so as to reduce the misjudgment that might occur. But AHP has disadvantages, namely: (1) It can not be used for interdependent criteria and alternatives. For this case ANP can be used (Azwir, 2017), (2) Allow inconsistencies in the assessment process so that the assessment must be repeated.

The TOPSIS method has the following characteristics (Tzeng and Huang, 2011): (1) Using the approach of an ideal solution of a problem, so that each criterion is treated proportionally according to the ideal conditions that might occur. (2) Carry out direct weighting for quantitative data, without having to carry out a pairwise comparison assessment, so that the calculation results are more accurate. This covers the shortcomings of the AHP method which carries out pairwise comparison assessments on all types of data, both qualitative and quantitative. But TOPSIS has weaknesses, namely: (1) It does not take into account the correlation between criteria. (2) It is difficult to do weighting, potentially wrong judgment. (3) It is difficult to maintain consistency.

The advantages of the AHP and TOPSIS methods can be used to complement each other, so that the integration between the AHP and TOPSIS models will have a strong weighting basis because it is done by pairwise comparison assessment and consistency checking, while the final weighting will be more ideal because it takes into account the solution ideal that might occur in such cases.

The purpose of the research carried out is to: (1) Develop appropriate methods for selecting suppliers at MTM. (2) Determine the criteria used by MTM as the basis for selecting suppliers. (3) Determine which suppliers are the most suitable to be the upper arm and lower arm pantograph jack suppliers at MTM.

(4) Determine whether supplier selection supports the cost reduction program at MTM.

\section{Research methods}

The data collection phase begins with collecting primary data, namely by engaging directly in the procurement process carried out by MTM. From this we get the purchasing data of pantograph jack components in MTM for a year, planned purchases in the current year, purchase prices that have been obtained, and prospective suppliers who submit bid prices for pantograph jack components, namely the upper arm and lower arm.

In addition, to complete the data to be processed using the AHP and TOPSIS methods, interviews were conducted with parties directly related to the procurement process, namely with the purchasing manager and supplier development team consisting of purchasing staff, engineering staff and quality staff. Data taken from this interview process includes purchasing criteria data used by MTM, priority data for supplier selection criteria taken from expert opinions, assessment data of each supplier candidate based on agreed criteria, and others. From the criteria data, sub criteria and alternative supplier data available, a hierarchical decision making model is formed, in accordance with the rules in the formation of the AHP model.

After all the necessary data has been collected, the data processing can begin. In processing this data, appropriate software tools are used for the analytical hierarchy process, namely Expert Choice 11 software, where calculations previously performed manually using Microsoft Excel will be done automatically with Expert Choice 11 software, namely by entering the criteria used in the supplier selection process in Expert Choice 11 and its selection sub-criteria. After that, Expert Choice 11 software can be run to perform analytical hierarchy process calculations. The result of these calculations is the global weight of each sub-criteria that will be input in calculations with the TOPSIS method.

TOPSIS analysis aims to get the best solution based on the shortest distance from the positive ideal solution and the farthest distance from the negative ideal solution. The data used in the TOPSIS analysis uses AHP calculation data that was done previously, namely the global weighting of sub criteria. In addition, the calculation of TOPSIS requires assessment data to alternatives in each of the existing sub-criteria.

The TOPSIS method requires alternative assessment data in the form of quantitative data. If a portion of the alternative assessment data is still in the form of qualitative data, a process of quantifying the data is carried out. The TOPSIS method does not have a definite way to carry out the process, therefore, the method used by the AHP in quantifying 
qualitative data. That is by pairwise comparison assessment. The results of the pairwise comparison assessment with the results of the global weighting sub-criteria were analyzed to get a positive ideal solution and a negative ideal solution from the model. After that, calculate the distance from each alternative to the ideal solution to get the highest value alternative was chosen.

From the calculation and analysis process using Expert Choice 11 software, then proceed with the TOPSIS method, the final weight of each supplier is obtained. From this it can be concluded whether MTM is succeed to use the analytical hierarchy process method and TOPSIS in determining suppliers who will supply their products. Then what are the right criteria for use in making these decisions. Another conclusion that can be drawn is which supplier will be a supplier of upper arm and lower arm pantograph jack components, because MTM applies the concept of multi sourcing to ensure the continuous supply of its products. The final conclusion is the amount of cost reduction obtained from the supplier selection process, whether the price obtained is more competitive than the acquisition price of the old supplier.

\section{Results and Discussion}

\section{Decision Making Model}

From interviews with all party that involved in selection process (explain in Methods), and also refer to criteria described by Weber
(Weber, 1991), there are five criteria that should be used by MTM in selecting suppliers, namely price criteria, quality criteria, production facilities \& capacity criteria, technical capabilities criteria and delivery criteria. In addition, interviews were also conducted to find out the parameters used to measure each of these criteria. From this discussion a decision model was produced as shown in Figure 3.

Two criteria will be exlain in more detail here. Production facilities are one of the important criteria in producing goods. This criterion is measured by two sub criteria: (1). 400 tons press stamping machine readiness. To produce upper arm and lower arm pantograph jack components, a press stamping machine with a tonnage of at least 400 tons is required, based on analysis performed by MTM. 2. Die making and die manufacturing facilities. In addition to machine readiness, stamping production also requires special dies that are compatible with the upper arm and lower arm pantograph jack products. With a fairly complex product design and requires a lot of processes, it is recommended by the engineering to use die progressive. This progressive die will make the production process more effective and efficient. To support the process of using progressive dies, adequate die making and die maintenance facilities are needed, both in terms of human and machine resources for the manufacture and maintenance of these dies. By having these facilities, making and maintaining the die

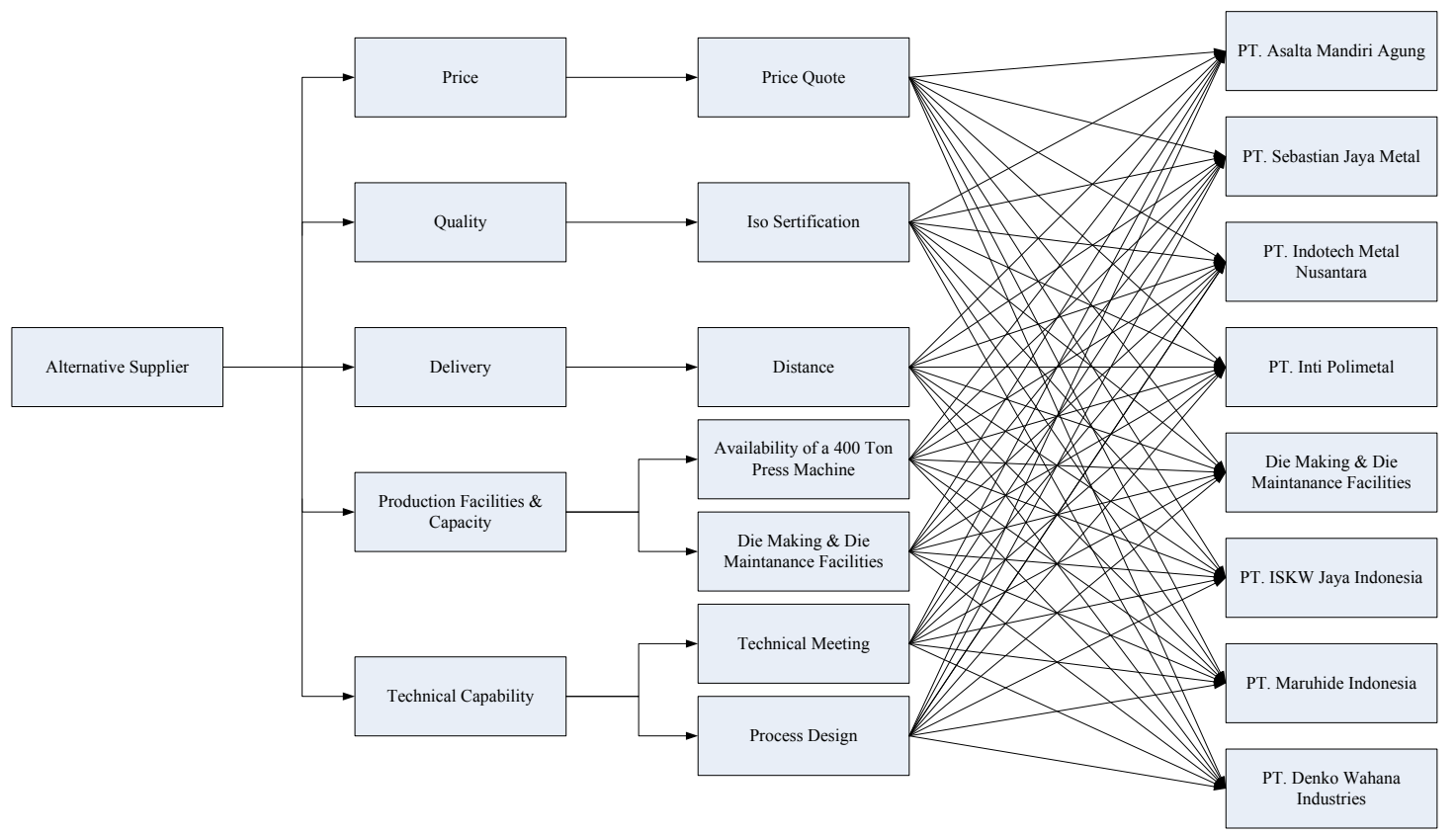

Figure 3. Decision Model 
required is faster, thereby reducing the potential for production stops due to die failure.

Technical capability owned by the engineer from the supplier will largely determine the process design and die design, so that it will greatly affect the production results. This technical capability criterion can be measured from two parameters that can be evaluated before the production process is carried out: (1) Technical meeting. In the early stages when MTM offers project upper arm and lower arm pantograph jack, there was a technical meeting between MTM purchasing with the marketing of the supplier, and also involving their respective engineering teams. From the technical meeting, the supplier will explain and describe the sequence of processes and dies to be used. From this explanation, MTM can evaluate the capability of the supplier has to produce the upper arm and lower arm pantograph jack. (2) Process Design. Process design is a production concept of the upper arm and lower arm pantograph jack components. This concept is important because in the production process using progressive die, there are several processes that will be carried out simultaneously in one die. The process design is a general description of the completeness of the process that will be used along with the sequence of the process. This design will determine the production results, the tonnage of the machines needed, and the cycle time of the production process.

To meet consumer demand in lowering Pantograph jack sales prices, MTM has multisourcing for upper arm and lower arm components for flange type pantograph jacks. The supplier development team conducted a study of several potential suppliers to produce and supply the upper arm and lower arm Pantograph jack components.
Results of the study finds eight prospective suppliers to be evaluated by the supplier development team, to determine which suppliers were appropriate to supply the product.

\section{AHP weighting}

From the results of interviews with MTM purchasing managers, data on the importance of criteria among the criteria used to conduct supplier selection were obtained. The most important criteria of the pairwise comparison assessment process are the price and quality criteria. From the results of the data processing, we get a comparison between criteria as shown in Table 1.

To simplify calculations, pairwise comparison assessment data is processed using Expert Choice 11 software to obtain normalized data. From the results of the calculation of Expert Choice 11, weights obtained between the supplier selection criteria are shown in Table 2.

Besides doing weighting calculations, Expert Choice 11 software also assesses the consistency ratio. The calculation results show that the inconsistency ratio in the assessment of pairwise comparisons between these criteria is 0.01. With a maximum allowable inconsistency ratio of 0.1 , the pairwise comparison assessment is consistent.

\section{TOPSIS weighting}

Of the seven sub-criteria that have been weighted, assessment data taken for each alternative by the interview method with the supplier development team whose task is to analyze and assess all alternative suppliers who have offered price quotes. Assessments are shared with each team member who is authorized to provide an assessment of alternative suppliers.

Table 1. Pairwise comparisons between criteria

\begin{tabular}{|l|l|l|l|l|l|}
\hline & Price & Quality & Delivery & $\begin{array}{l}\text { Production } \\
\text { Facilities\& } \\
\text { Capacity }\end{array}$ & $\begin{array}{l}\text { Technical } \\
\text { Capability }\end{array}$ \\
\hline Price & 1.00 & 1.00 & 5.00 & 3.00 & 2.00 \\
\hline Quality & 1.00 & 1.00 & 5.00 & 3.00 & 1.00 \\
\hline Delivery & 0.20 & 0.20 & 1.00 & 1.00 & 0.33 \\
\hline $\begin{array}{l}\text { Production Facilities \& } \\
\text { Capacity }\end{array}$ & 0.33 & 0.33 & 1.00 & 1.00 & 0.33 \\
\hline Technical Capability & 0.50 & 1.00 & 3.00 & 3.00 & 1.00 \\
\hline
\end{tabular}


Table 2. Global weight of sub-criteria AHP weighting results

\begin{tabular}{|c|c|c|c|c|c|}
\hline No & Criteria & $\begin{array}{l}\text { Weight } \\
\text { Criteria }\end{array}$ & Sub-criteria & $\begin{array}{l}\text { Weight } \\
\text { Sub-criteria }\end{array}$ & $\begin{array}{l}\text { Global Weighting } \\
\text { Sub-Criteria }\end{array}$ \\
\hline 1 & Price & 0.331 & Price Quote & 1.000 & 0.331 \\
\hline 2 & Quality & 0.331 & ISO Sertification & 1.000 & 0.331 \\
\hline 3 & Delivery & 0.077 & $\begin{array}{l}\text { Distance from PT. } \\
\text { Menara Terus } \\
\text { Makmur }\end{array}$ & 1.000 & 0.077 \\
\hline \multirow{2}{*}{4} & \multirow{2}{*}{$\begin{array}{l}\text { Production } \\
\text { Facilities \& } \\
\text { Capacity }\end{array}$} & \multirow{2}{*}{0.095} & $\begin{array}{l}400 \text { Ton Press } \\
\text { Machine Availability }\end{array}$ & 0.667 & 0.063 \\
\hline & & & $\begin{array}{l}\text { Die Making \& Die } \\
\text { Maintenance Facility }\end{array}$ & 0.333 & 0.032 \\
\hline \multirow{2}{*}{5} & \multirow{2}{*}{$\begin{array}{l}\text { Technical } \\
\text { Capability }\end{array}$} & \multirow{2}{*}{0.167} & Technical Meeting & 0.250 & 0.042 \\
\hline & & & Process Design & 0.750 & 0.125 \\
\hline \multicolumn{2}{|c|}{ Total } & 1.001 & \multicolumn{2}{|l|}{ Total } & 1.001 \\
\hline
\end{tabular}

The appointed team consists of three people from different departments, namely one person from the Purchasing Department, one person from the Engineering Department, and one person from the Quality Department.

Data on alternative suppliers is obtained during the development process by holding a meeting and asking for some data relating to the assessment to be carried out. The assessment data will be used as calculation material in the analysis using the TOPSIS method. However, TOPSIS analysis requires alternative quantitative assessment data. Qualitative data must be converted into quantitative form before being processed using the TOPSIS method.

From the summary of supplier alternative assessment data based on seven predefined sub-criteria, two sub-criteria data are in the form of quantitative data, while the other five data are still in the form of qualitative data.
Therefore, the qualitative data needs to be converted into quantitative data by the pairwise comparison assessment method held by the AHP method. The results of the pairwise comparison assessment process will be in the form of quantitative data and can be processed using the TOPSIS method. Table 3 shows the results of the weight calculation for each criterion for each supplier obtained through Expert Choice 11 software.

From the decision matrix that has been formed, it is processed to get the normalization matrix. Then in the TOPSIS analysis proceed with the formation of a weighted normalized decision matrix, the results of which can be seen in Table 4.

Next is determining the positive ideal solution $(\mathrm{A}+)$ and the negative ideal solution (A-) of each sub-criteria that can be shown in Table 5. Determination of value is based on the minimum and maximum values contained in the same column or criteria.

Table 3.TOPSIS decision matrix

\begin{tabular}{|c|c|c|c|c|c|c|c|c|}
\hline No & Supplier & $\begin{array}{l}\frac{0}{0} \\
\stackrel{0}{2} \\
0 \\
0 \\
.00 \\
0 \\
0\end{array}$ & 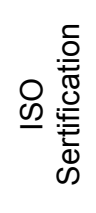 & 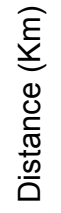 & 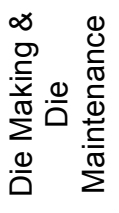 & 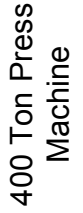 & 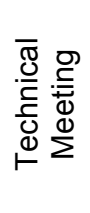 & 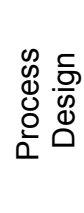 \\
\hline 1 & PT. Asalta Mandiri Agung & 16,325 & 0.136 & 64 & 0.286 & 0.15 & 0.024 & 0.024 \\
\hline 2 & PT. Sebastian Jaya Metal & 9,349 & 0.136 & 4 & 0.286 & 0.15 & 0.140 & 0.102 \\
\hline 3 & $\begin{array}{l}\text { PT. Indotech Metal } \\
\text { Nusantara }\end{array}$ & 8,359 & 0.246 & 26 & 0.071 & 0.15 & 0.331 & 0.146 \\
\hline 4 & PT. Inti Polymetal & 11,442 & 0.136 & 26 & 0.071 & 0.15 & 0.140 & 0.227 \\
\hline 5 & PT. ISKW Java Indonesia & 8,022 & 0.036 & 21 & 0.071 & 0.05 & 0.140 & 0.227 \\
\hline 6 & PT. Maruhide Indonesia & 11,603 & 0.036 & 21 & 0.071 & 0.15 & 0.025 & 0.024 \\
\hline 7 & PT. Nirmala Tirta Putra & 12,974 & 0.136 & 107 & 0.071 & 0.15 & 0.059 & 0.024 \\
\hline 8 & $\begin{array}{l}\text { PT. Denko Wahana } \\
\text { Industries }\end{array}$ & 7,990 & 0.136 & 16 & 0.071 & 0.05 & 0.140 & 0.227 \\
\hline
\end{tabular}


Table 4. The normalized decision matrix is weighted

\begin{tabular}{|c|c|c|c|c|c|c|c|c|}
\hline No & Supplier & $\begin{array}{l}\frac{0}{ \pm} \\
\frac{\pi}{2} \\
0 \\
0 \\
.00 \\
0 \\
0\end{array}$ & 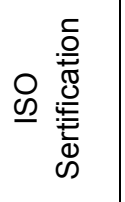 & 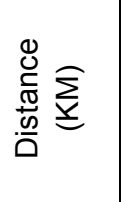 & 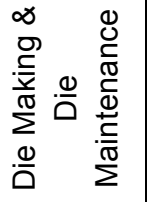 & 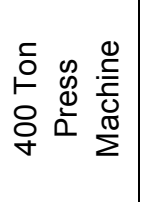 & 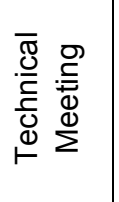 & 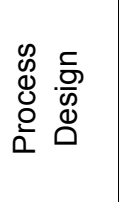 \\
\hline 1 & PT. Asalta Mandiri Agung & 0.1721 & 0.1141 & 0.0367 & 0.0412 & 0.0127 & 0.0023 & 0.0069 \\
\hline 2 & PT. Sebastian Jaya Metal & 0.0986 & 0.1141 & 0.0023 & 0.0412 & 0.0127 & 0.0133 & 0.0295 \\
\hline 3 & PT. Indotech Metal Nusantara & 0.0881 & 0.2064 & 0.0149 & 0.0102 & 0.0127 & 0.0315 & 0.0422 \\
\hline 4 & PT. Inti Polymetal & 0.1206 & 0.1141 & 0.0149 & 0.0102 & 0.0127 & 0.0133 & 0.0656 \\
\hline 5 & PT. ISKW Java Indonesia & 0.0846 & 0.0302 & 0.0120 & 0.0102 & 0.0042 & 0.0133 & 0.0656 \\
\hline 6 & PT. Maruhide Indonesia & 0.1223 & 0.0302 & 0.0120 & 0.0102 & 0.0127 & 0.0024 & 0.0069 \\
\hline 7 & PT. Nirmala Tirta Putra & 0.1368 & 0.1141 & 0.0613 & 0.0102 & 0.0127 & 0.0056 & 0.0069 \\
\hline 8 & PT. Denko Wahana Industries & 0.0842 & 0.1141 & 0.0092 & 0.0102 & 0.0042 & 0.0133 & 0.0656 \\
\hline
\end{tabular}

After the ideal solution is obtained then continue to look for the distance between the normalized decision matrix data weighted with a positive ideal solution $\left(\mathrm{S}^{+}\right)$and a negative ideal solution (S-). This distance calculation is done for each alternative supplier for all existing sub-criteria. The results of the calculation of the distances from these positive and negative ideal solutions are shown in
Based on the results obtained in Table 6, finally the final weight can be calculated through the relative closeness between each supplier with the ideal solution which is to determine the value of $\mathrm{Ci}+$. The final results from supplier ratings are shown in Table 7 . From the results of the analysis, PT. Indotech Metal Nusantara is a top priority as a supplier with a weight of $21 \%$.

Table 5. The positive ideal solution and the negative ideal solution

\begin{tabular}{|c|c|c|c|c|c|c|c|c|}
\hline \multicolumn{2}{|c|}{ Solution } & $\begin{array}{l}\text { Price } \\
\text { Quote }\end{array}$ & $\begin{array}{l}\text { ISO } \\
\text { Sertification }\end{array}$ & $\begin{array}{l}\text { Distance } \\
(\mathrm{KM})\end{array}$ & $\begin{array}{lr}\text { Die } & \text { Making } \\
\& & \text { Die } \\
\text { Maintenance }\end{array}$ & $\begin{array}{l}400 \text { Ton } \\
\text { Press } \\
\text { Machine }\end{array}$ & $\begin{array}{l}\text { Technical } \\
\text { Meeting }\end{array}$ & $\begin{array}{l}\text { Process } \\
\text { Design }\end{array}$ \\
\hline \multirow{2}{*}{$A+$} & \multirow{2}{*}{$\begin{array}{l}\text { Positive } \\
\text { Ideal } \\
\text { Solution }\end{array}$} & Min & Max & Min & Max & Max & Max & Max \\
\hline & & 0.0842 & 0.2064 & 0.0023 & 0.0412 & 0.0127 & 0.0315 & 0.0656 \\
\hline \multirow{2}{*}{$A-$} & \multirow{2}{*}{$\begin{array}{l}\text { Negative } \\
\text { Ideal } \\
\text { Soluton }\end{array}$} & Max & Min & Max & Min & Min & Min & Min \\
\hline & & 0.1721 & 0.0302 & 0.0613 & 0.0102 & 0.0042 & 0.0023 & 0.0069 \\
\hline
\end{tabular}

Table 6. Distance to normalized decision matrix data weighted

\begin{tabular}{|c|l|c|c|}
\hline No & \multicolumn{1}{|c|}{ Supplier } & S+ & S- \\
\hline 1 & PT. Asalta Mandiri Agung & 0.147 & 0.093 \\
\hline 2 & PT. Sebastian Jaya Metal & 0.102 & 0.133 \\
\hline 3 & $\begin{array}{l}\text { PT. Indotech Metal } \\
\text { Nusantara }\end{array}$ & 0.041 & 0.206 \\
\hline 4 & PT. Inti Polymetal & 0.106 & 0.124 \\
\hline 5 & PT. ISKW Java Indonesia & 0.180 & 0.117 \\
\hline 6 & PT. Maruhide Indonesia & 0.195 & 0.071 \\
\hline 7 & PT. Nirmala Tirta Putra & 0.141 & 0.092 \\
\hline 8 & $\begin{array}{l}\text { PT. Denko Wahana } \\
\text { Industries }\end{array}$ & 0.100 & 0.145 \\
\hline
\end{tabular}

Table 7. Alternative priorities of TOPSIS analysis results

\begin{tabular}{|c|l|c|c|}
\hline No & \multicolumn{1}{|c|}{ Supplier } & $\% \mathrm{Ci}+$ & Rangking \\
\hline 1 & $\begin{array}{l}\text { PT. Indotech Metal } \\
\text { Nusantara }\end{array}$ & $21.0 \%$ & 1 \\
\hline 2 & $\begin{array}{l}\text { PT. Denko Wahana } \\
\text { Industries }\end{array}$ & $14.9 \%$ & 2 \\
\hline 3 & PT. Sebastian Jaya Metal & $14.2 \%$ & 3 \\
\hline 4 & PT. Inti Polymetal & $13.6 \%$ & 4 \\
\hline 5 & PT. Nirmala Tirta Putra & $9.9 \%$ & 5 \\
\hline 6 & PT. ISKW Java Indonesia & $9.9 \%$ & 6 \\
\hline 7 & PT. Asalta Mandiri Agung & $9.7 \%$ & 7 \\
\hline 8 & PT. Maruhide Indonesia & $6.7 \%$ & 8 \\
\hline
\end{tabular}


Table 8. Purchase costs before the supplier selection process

\begin{tabular}{|l|l|l|c|c|c|c|}
\hline No & \multicolumn{1}{|c|}{ Supplier } & Component & $\begin{array}{c}\text { Price } \\
\text { (Rupiah) }\end{array}$ & $\begin{array}{c}\text { Qty } \\
\text { /Set }\end{array}$ & $\begin{array}{c}\text { Qty PJ } \\
\text { (Set) }\end{array}$ & $\begin{array}{c}\text { Total Cost } \\
\text { (Rupiah) }\end{array}$ \\
\hline 1 & $\begin{array}{l}\text { PT. Indotech Metal } \\
\text { Nusantara }\end{array}$ & Lower arm & 4,859 & 2 & 40,000 & $388,720,000$ \\
\hline 2 & $\begin{array}{l}\text { PT. Indotech Metal } \\
\text { Nusantara }\end{array}$ & Upper arm & 4,609 & 2 & 40,000 & $368,720,000$ \\
\hline \multicolumn{5}{|c|}{ Total } & 40,000 & $757,440,000$ \\
\hline
\end{tabular}

\section{Cost Reduction}

By diverting a part of the order to PT. Denko Wahana Industries and new price adjustments from PT. Indotech Metal Nusantara, then MTM obtained a reduction in the cost of purchasing upper arm and lower arm pantograph jack components which are calculated in accordance with the one-year forecase given by the customer. This calculation will compare the total purchases of the upper arm and lower arm pantograph jack components before the supplier selection process, which is shown in Table 8 , with the total purchases after the supplier process, with the same purchase quantity, shown in Table 9.

\section{Conclusion}

From the research and analysis conducted, the following conclusions can be drawn: (1) Analytical Hierarchy Process (AHP) method integrated with the Technique for Order Preference by Similarity of Ideal Solution (TOPSIS) method is able to complete the supplier selection process for upper arm and lower components arm pantograph jack at PT. Menara Terus Makmur (MTM) and methodologically accountable. (2) There are five criteria used by the supplier development team of PT. Menara Terus Makmur (MTM) in analyzing and selecting the most appropriate suppliers, namely the criteria of price, quality, delivery, production facilities \& capacity, and

Table 9. Purchase costs after the supplier selection process

\begin{tabular}{|c|l|c|c|c|c|c|}
\hline No & \multicolumn{1}{|c|}{ Supplier } & Component & $\begin{array}{c}\text { Price } \\
\text { (Rupiah) }\end{array}$ & Qty/ Set & $\begin{array}{c}\text { Qty PJ } \\
\text { (Set) }\end{array}$ & $\begin{array}{c}\text { TotalCost } \\
\text { (Rupiah) }\end{array}$ \\
\hline 1 & $\begin{array}{l}\text { PT. Indotech Metal } \\
\text { Nusantara }\end{array}$ & Lower arm & 4,274 & 2 & 16,000 & $136,768,000$ \\
\hline 2 & $\begin{array}{l}\text { PT. Indotech Metal } \\
\text { Nusantara }\end{array}$ & Upper arm & 4,085 & 2 & 16,000 & $130,720,000$ \\
\hline 3 & $\begin{array}{l}\text { PT. Denko Wahana } \\
\text { Industries }\end{array}$ & Lower arm & 4,120 & 2 & 24,000 & $197,755,650$ \\
\hline 4 & $\begin{array}{l}\text { PT. Denko Wahana } \\
\text { Industries }\end{array}$ & Upper arm & 3,870 & 2 & 24,000 & $185,756,550$ \\
\hline & \multicolumn{2}{|l}{ Total } & 40,000 & $651,000,200$ \\
\hline
\end{tabular}

Based on data from Tables 8 and 9, it can be calculated that the cost reduction obtained within a period of one year for the flange type of pantograph jack products from the purchase of components of the upper arm and lower arm is $\operatorname{Rp} 757,440,000-\operatorname{Rp} 651,000,200=R p$ $106,439,800,-$. Aside from the cost reduction aspect, the risk aspect to the failure of supply of pantograph jack products is reduced by the presence of two suppliers who supply upper arm and lower arm components compared to only relying on one supplier. components of the upper arm and lower arm pantograph jacks decreased. With a $40 \%$ order distribution to PT. Indotech Metal Nusantara, and $60 \%$ for PT. Denko Wahana Industries, the cost decreased by $\operatorname{Rp} 106,439,800$ per year. Suggestions that can be given from the research conducted are: (1) Further research on supplier selection should consider the dependency between the criteria, sub-criteria and feedback between the components. (2) Adding several sub-criteria for the Quality criteria with the rejection rate sub-criteria, because this can help illustrate the performance quality of the supplier candidate. 


\section{Bibliography}

Azwir, H. H. (2017). Pemilihan supplier menggunakan metode analytic network process di PTUnited Tractors Pandu Engineering. Jurnal Teknik Industri, 18(2), 103.

https://doi.org/10.22219/JTIUMM.Vol18.No 2.103-112

Baker, D., Bridges,D., Hunter,R., Johnson,G., Krupa,J.,Murphy,J.,Sorenson,K. . 2002 Guidebook to Decision Making Methods.WSRC-WM-2002-00002, Department of Energy, USA.

Greco, S., Ehrgott, M., \& Figueira, J. R. (2016). Mutiple criteria decision analysis: State of the art surveys. Volume 1 (Second edition). New York: Springer Science+Business Media.

Hanine, M., Boutkhoum, O., Tikniouine, A., \& Agouti, T. (2016). Application of an integrated multi-criteria decision making AHP-TOPSIS methodology for ETL software selection. SpringerPlus, 5(1). https://doi.org/10.1186/s40064-016-1888-z

Jabbarzadeh, A. (2018). Application of the AHP and TOPSIS in project management. Journal of Project Management, 125-130. https://doi.org/10.5267/j.jpm.2018.1.001

Karim, R., \& Karmaker, C. L. (2016). Machine Selection by AHP and TOPSIS Methods. American Journal of Industrial Engineering, $4(1), 7-13$.

Munir, M. (2017). Pemilihan Supplier Sodium Hiroxide Liquid Integrasi Dengan Metode AHP - Topsis. Jurnal Teknik Industri, 17(2), 62.
https://doi.org/10.22219/JTIUMM.Vol17.No 2.62-71

Nilsson, H., Nordström, E.-M., \& Öhman, K. (2016). Decision Support for Participatory Forest Planning Using AHP and TOPSIS. Forests, 7(12), 100. https://doi.org/10.3390/f7050100

Saaty, L Thomas, 1993, "Pengambilan Keputusan Bagi Para Pemimpin", edisi 1, alih bahasa oleh Liana dan Kirin, Jakarta: Pustaka Binaman Presindo

Sari, D. R., Windarto, A. P., Hartama, D., \& Solikhun, S. (2018). Sistem Pendukung Keputusan untuk Rekomendasi Kelulusan Sidang Skripsi Menggunakan Metode AHPTOPSIS. Jurnal Teknologi dan Sistem Komputer, 6(1), 1. https://doi.org/10.14710/jtsiskom.6.1.2018.1 $-6$

Tzeng, Gwo-Hsiung dan Jih-Jeh Huang.2011. Multiple Attribut Decision Making: Methode \& Application. CRC Press, LLC, United States

Weber, Charles A., Current, John R.,Benton W.C.1991.Vendor Selection Criteria and Methods. European Journal of Operational Research, 50 PP 2-18, North Holland.

Yildiz, S., \& Yildiz, E. (2015). Service Quality Evaluation of Restaurants Using the AHP and TOPSIS Method. Journal of Social and Administrative Sciences, 2(2), 9.

Zopounidis, C., \& Doumpos, M. (2016). Multiple criteria decision making: Applications in management and engineering. New York, NY: Springer Berlin Heidelberg. 
DOI: https://doi.org/10.26593/jrsi.v9i1.3423.1-10

Halaman ini sengaja dikosongkan

This page is intentionally left blank 